\title{
The Influence of Auditory-Feedback Device Using Wearable Air-Pressure Insole on Spatiotemporal Gait Symmetry in Chronic Hemplegia
}

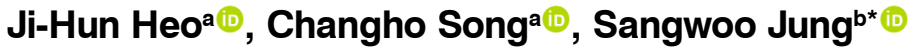 \\ ${ }^{a}$ Department of Physical Therapy, College of Health and Welfare, Sahmyook University, Seoul, Republic of Korea \\ $\mathbf{b}^{*}$ Department of Sport Rehabilitation, Gimcheon University, Gimcheon-si, Republic of Korea
}

Objective: To investigate the effect of emphasized initial contact by using a wearable air-pressure insole to provide auditoryfeedback with variations of maximum peak pressure (MPP) of the affected side on spatiotemporal gait parameters and gait symmetry of stroke patients

Design: A cross-sectional study

Methods: Eighteen stroke patients participated in this study. All subjects walked five trials using an air-pressure insole that provides auditory feedback with different thresholds set on the insole. First, subjects walked without any auditory feedback. Then, the MPP threshold on the affected side was set from $70 \%$ and increase threshold by $10 \%$ after each trial until $100 \%$. They walked three times or more on the gait analyzer for each trial, and the average values were measured. Before starting the experiment, subjects measured body weight, initial gait abilities and affected side MPP without auditory feedback.

Results: Temporal and spatial variables were significantly increased in trials with auditory feedback from air-pressure insole except for non-paralyzed single support time and spatial gait symmetry compared to trials without auditory feedback $(\mathrm{p}<0.05)$. Among the four different thresholds, the walking speed, unaffected side single support time, affected and unaffected side stride, and affected side step length were greatest at $80 \%$ threshold of maximum peak, while affected single support time, temporal gait symmetry, and unaffected step length were greatest at the maximum peak of $100 \%$ threshold.

Conclusions: These results indicate that auditory feedback gait using air-pressure insoles can be an effective way to improve walking speed, single support time, step length, stride, and temporal gait symmetry in stroke patients.

Key Words: Pressure insole, Stroke, Gait, Auditory feedback

서론

연구의 배경 및 필요성

뇌졸중은 뇌혈관의 허혈 또는 출혈의 원인으로 인해 발 생하는 질환이다[1]. 뇌졸중은 전 세계적으로 가장 큰 장 애 원인 중 하나이며, 세계 발병률은 2030년까지 1530만 명에서 2300만으로 증가할 것으로 예상된다[2].

뇌졸중으로 인한 대뇌의 운동 시스템이 손상되면 신체 장애와 보행 기능 장애가 발생하며 뇌졸중 환자의 $60 \%$ 가 걷기에 어려움을 겪고 있으며 $30 \%$ 이상은 병변 발생 직
후 6개월 동안 도움 없이는 걸을 수 없다[3][4]. 뇌졸중으 로 인한 편측 부전 마비 환자는 비마비측 하지에 대한 의 존도가 높아져 비대칭적인 균형과[5] 보행이[6][7] 나타난 다. 비대칭적인 보행은 뇌졸중 발병 후 대표적인 기능적 인 제한이며, 보행 능력의 회복은 뇌졸중 재활의 가장 중 요한 목표이다[8]. 뇌졸중 환자의 비대칭적인 보행은 감소 된 동적 균형능력과 효율적인 보행 능력과 관련된 일상 생활 동작 수행 능력이 저하되고[9][10], 낙상 위험이 증 가한다[11].

비대칭적인 보행의 특징은 비마비측 하지에서 유각기 시간이 늘어나고 마비측 하지에서는 단일 지지기 시간이

Received: Aug 5, 2021 Revised: Sep 12, 2021 Accepted: Sep 12, 2021

Corresponding author: Sangwoo Jung (ORCID https://orcid.org/0000-0003-2577-9180)

Department of Sport Rehabilitation, Gimcheon University, 214, Daehak-ro, Gimcheon-si,Republic of Korea.

Tel: +82-10-8851-1877, Fax: +8254-420-4003, E-mail: tkddn95@hanmail.net

This is an Open-Access article distributed under the terms of the Creative Commons Attribution Non-Commercial License (http://creativecommons.org/licenses/ by-nc/4.0) which permits unrestricted non-commercial use, distribution, and reproduction in any medium, provided the original work is properly cited. Copyright (C) 2021 Korean Academy of Physical Therapy Rehabilitation Science 
감소하며 이러한 결과는 비대칭적인 입각기, 유각기, 보폭 길이가 나타난다[12]. 뇌졸중 환자는 운동 신경 손상으로 인해 보행 시 마비측 하지에 발등 굽힘이 제한적으로 나 타나며[13], 초기 입각기 시 발뒤꿈치가 지면에 접촉하기 어려워 마비측 하지의 지지기 시간과 보폭이 감소한다 [14]. 또한, 뒤꿈치의 최대 압력은 매우 제한되고 발의 활 성 영역은 앞발과 발가락으로 나타나게 되며 뇌졸중 환자 의 보행 속도와 보행 지속성이 감소하게 된다[15][16]. 따 라서, 대칭적인 보행을 회복하는 것은[17][18] 일상생활 기능 제한 및 지역 사회 내에 이동에 장기적인 영향을 줄 수 있기 때문에 재활의 중요한 목표이다[9][19][20].

뇌졸중 환자 보행 기능 장애를 회복하기 위한 연구는 바이오 피드백 훈련[21], 가상 현실 훈련[22], 기능적 전 기 자극 훈련[16], 로봇 보조 보행 훈련[23] 등의 중재 방 법이 연구되었고 보행 개선의 효과를 나타내었다.

그 중 바이오 피드백 보행 훈련은 시각, 청각 및 촉각 과 같이 다양한 감각을 통해 실시되며, 뇌졸중 환자의 보 행 능력과 균형 능력을 향상하는 효과를 기대할 수 있다 [24][25][26]. 뇌졸중 환자에게 바이오 피드백은 환자에게 움직임에 대한 추가적인 감각 정보를 제공하여 동작 오류 를 찾고 수정할 수 있도록 한다[27].

최근에 바이오 피드백을 이용한 뇌졸중 환자 보행 훈련 은 인솔을 기반으로 한 압력 센서 시스템의 연구가 진행 되었다[15]. 압력 센서 인솔을 사용한 바이오 피드백 보행 훈련은 뇌졸중 환자에게 비대칭적인 보행 개선뿐만 아니 라 퇴원 후 환자 스스로 재활 동기를 부여를 증진시킬 수 있다[28].

뇌졸중 환자에게 압력 센서 인솔을 통한 청각적 피드백 보행 훈련은 일반적 보행 훈련보다 마비측 하지에 체중 부하와 보폭을 증가시켜 대칭적인 보행 능력을 회복하는 데 효과적이다[29][30]. 뇌졸중 환자에게 보행 중 인지와 관련된 과제가 추가되면 보행 능력이 감소할 수 있지만 [31], 인솔에 의한 경고음은 비교적 간단한 신호이므로 뇌 졸중 환자가 쉽게 집중할 수 있다. 이러한 청각적 피드백 은 발 위치, 기저면과 관련된 보행 안정성과 밀접한 관련 이 있다[32]. 청각적 피드백은 뇌졸중을 포함한 다양한 신 경 손상 및 또는 질병이 있는 환자의 보행 향상에 효과적 이다[18]. Sungkarat 등[33]은 압력 센서 인솔에 의한 청 각적 피드백 보행 훈련은 뇌졸중 환자의 시간적, 공간적 비대칭적인 보행 능력의 개선에 효과적이라고 하였으며, Kim 등[14]은 뇌졸중 환자의 마비측 발에 초기 입각기 시 뒤꿈치 닿기를 강조한 인솔을 착용하여 청각적 피드백 보행 훈련을 시행하였을 때 일반적 보행 훈련보다 균형과 보행 능력의 향상이 나타났다고 보고하였다.

이전 연구에서 뇌졸중 환자의 일반적 보행 훈련과 다양 한 형태의 압력 센서 인솔을 착용한 청각적 피드백 보행
훈련의 효과를 비교하는 연구가 진행되었고, 압력 피드백 신호의 역치값에 관한 비교 연구가 부족하여 역치값의 변 화에 따른 시간적, 공간적 보행 변수의 변화에 관한 연구 가 필요하다.

본 연구는 뇌졸중 환자에게 청각적 피드백 장치와 뒤꿈 치 닿기를 강조한 공기압 인솔을 착용하여 마비측 체중 역치값에 따른 뇌졸중 환자의 시간적, 공간적 보행 변수 와 대칭성의 변화를 알아보고자 하며 더 나아가 공기압 인솔을 이용한 뇌졸중 보행 훈련 방법을 선정하는 데 있 어 기초 자료로 활용하고자 한다.

\section{연구 방법}

\section{연구 대상}

본 연구의 대상자는 경기도 일산시에 위치하고 있는 $\mathrm{M}$ 재활병원에 입원 치료 중인 18 명의 뇌졸중 환자를 대상으 로 하였다. 연구 대상자의 선정기준은 연구자가 지시한 내용을 이해하고 따를 수 있는 한국형 간이정신상태 판별 검사(Korean version of Mini-Mental State Exam) 점수 가 22점 이상인 자, 시간적, 공간적 보행 변수 측정을 위 해 독립적으로 $10 \mathrm{~m}$ 이상 보행이 가능한 자로 하였다. 연 구 대상의 제외기준은 보행 훈련을 방해할 수 있는 합병 증을 동반한 자, 심한 다리 경직 Modified Ashworth Scale 3점 이상인 자, 편측 무시 증상이 있는 자로 선정하 였다.

연구에 참여한 모든 대상자에게 연구의 목적과 필요한 사항에 대해서 자세히 설명하였고, 연구 중 언제든지 연 구에 대한 참여를 철회할 수 있음을 설명한 후 동의서를 작성하였다. 본 연구는 삼육대학교 연구윤리 심의위원회 의 승인(승인번호: 2-7001793-AB-N-012019096HR)을 받 아 시행되었다.

\section{실험 절차}

본 연구는 선정기준을 적용하여 뇌졸중 환자 18 명을 대상으로 하였다. 실험 전 대상자의 성별, 연령, 신장, 체 중, 마비측 등의 일반적인 특성을 기록하고 난 후, 보행 분석기 위에서 3 회 이상 걷도록 하여 보행 능력과 인솔의 최대 피크 압력을 측정하였다. 실험 시작 전 인솔의 청각 적 피드백에 적응하기 위해 5 분 동안 마비측 인솔에 신호 음이 발생하도록 보행 연습을 시행하였다. 연습이 끝난 뒤 대상자들을 네 가지 역치값의 피드백 신호에 따라 보 행 분석기 위에서 걷도록 하여 보행 능력을 분석하였다. 첫 번째는 마비측 인솔에 대한 역치값을 최대 피크 압력 의 $70 \%$, 두 번째 방법은 마비측 인솔에 대한 역치값을 보행할 시 최대 피크 압력의 $80 \%$, 세 번째 방법은 마비 
측 인솔에 대한 역치값을 보행할 시 최대 피크 압력의 $90 \%$, 네 번째 방법은 마비측 인솔에 대한 역치값을 보행 할 시 최대 피크 압력의 $100 \%$ 가 되는 수치를 역치값으 로 설정하여 역치 이상의 체중 지지가 나타나도록 보행을 시행하였다. 순서에 의한 학습효과를 배제하기 위해 컴퓨 터로 정해진 무작위 순서에 따라 순서를 정하였다. 모든 보행 측정은 3 회 이상을 진행하였으며, 측정 간 1 분의 휴 식시간을 주었다.

\section{실험 방법}

\section{공기압인솔}

본 연구에 사용된 공기압 인솔은 보행 시 청각적 피드 백을 통해 체중 지지를 유도하도록 제작하였다. 뇌졸중 환자에게 뒤꿈치 닿기를 강조하기 위해 공기압 측정기를 발의 뒤쪽 부분에 위치하였다(Figure 1). 공기압 측정기는 인디케이터(indicator)와 연결되었으며, 인디케이터는 메 인 허브와 무선으로 연결이 되어있다(Figure 2). 메인 허 브는 케이블을 통해 들어오는 체중 부하량을 무선으로 연 결된 휴대폰 앱 화면에 실시간으로 전송할 수 있고, 인솔 의 압력 값을 실시간으로 저장하여 오른쪽, 왼쪽 인솔에 가해지는 최대 피크 압력을 측정하였다(Figure 3). 공기압 인솔을 착용하여 보행 시 마비측 인솔에 역치값 이상의 압력이 나타날 때 휴대폰에서 신호음을 통하여 대상자들 에게 청각적 피드백을 제공하였다.

인솔을 신발에 정확하게 착용하기 위해 한국 신발 크기

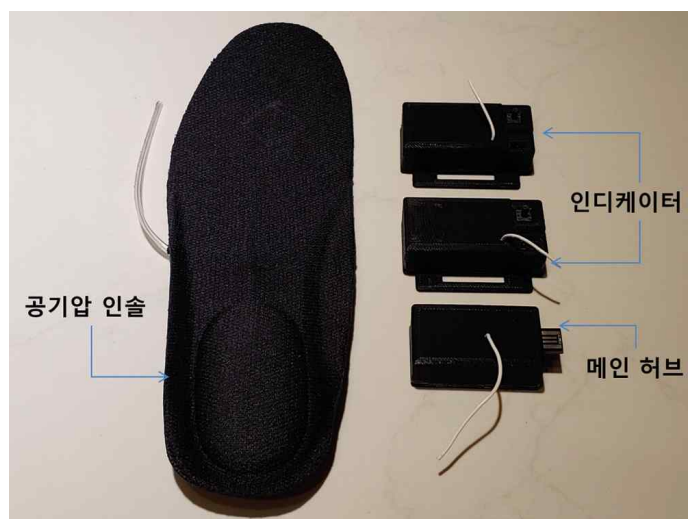

Figure 1. Air pressure insole

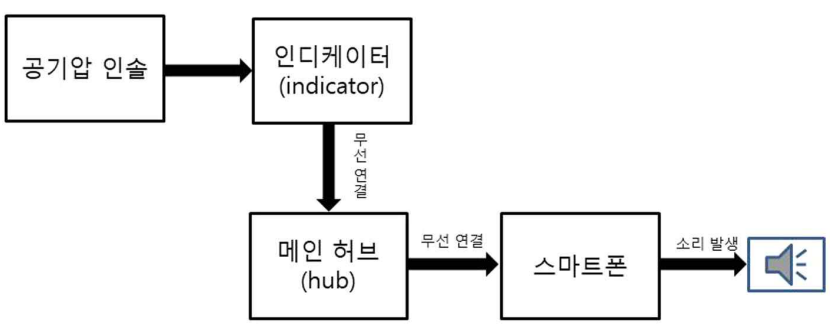

Figure 2. Diagram for air pressure insole connection
기준 $230 \mathrm{~mm}$ 부터 $280 \mathrm{~mm}$ 까지 $10 \mathrm{~mm}$ 단위로 준비하 였고, 대상자들이 평소에 신는 신발을 착용하여 실험을 진행하였다. 실험 시작 전 대상자들의 개별 체중을 측정 하기 위해 공기압 인솔을 착용하여 선 자세에서 1 분 동안 정면을 응시한 상태로 유지하도록 하여 공기압 측정기의 압력 감지에 의한 체중을 측정하였다. 대상자들의 평상시 보행 능력과 최대 피크 압력을 측정하기 위해 인솔을 착 용하여 청각적 피드백 없이 보행 분석기 위에서 3회 이상 걷도록 하였다. 청각적 피드백 보행을 시행하기 전 5분 동안 대상자들은 인솔의 청각적 피드백에 적응하기 위해 최대 피크 압력의 $70 \%$ 역치값으로 설정하여 마비측 공기 압 인솔에 체중 이동이 나타나도록 보행을 하였고, 신호 음이 발생 된 후 비마비측 다리가 움직일 수 있도록 교육 을 시행하였다. 측정 시작 시 모든 대상자에게 구두로 "마 비측 발에 소리가 나도록 체중을 실어보세요, 그리고 소 리가 날 때까지 마비측에 체중을 실으면서 걸어보세요." 라고 지시하였다.

\section{보행 분석기}

본 연구에서는 대상자의 시간적, 공간적 보행 능력을 측정하기 위해 보행 분석기(GAITRite version $3.2 \mathrm{~b}, \mathrm{CIR}$ systems Inc., USA)를 사용하였다(Figure 4). 연구에 사 용된 보행 분석기는 폭 $61 \mathrm{~cm}$, 길이 $366 \mathrm{~cm}$ 로 전기적 장치가 설비된 매트 형태이며, 대상자가 보행로 위를 걸 어서 지나가면, 보행속도, 분속수, 단일 지지기 시간등의

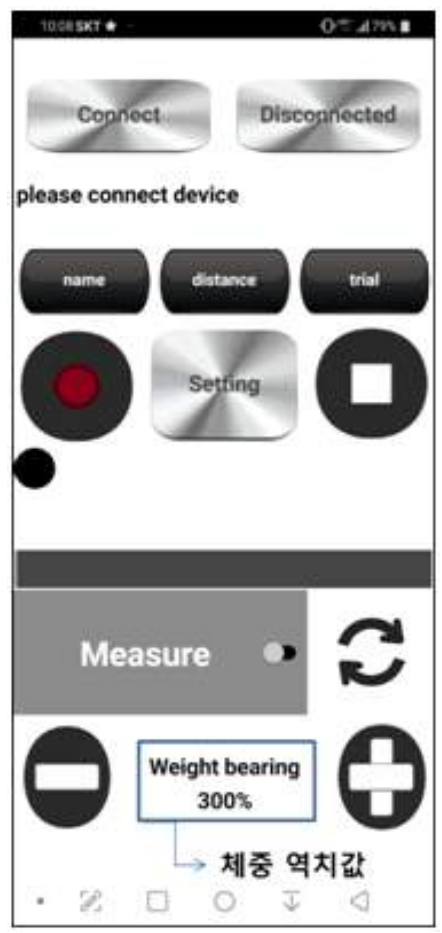

Figure 3. Mobile application 


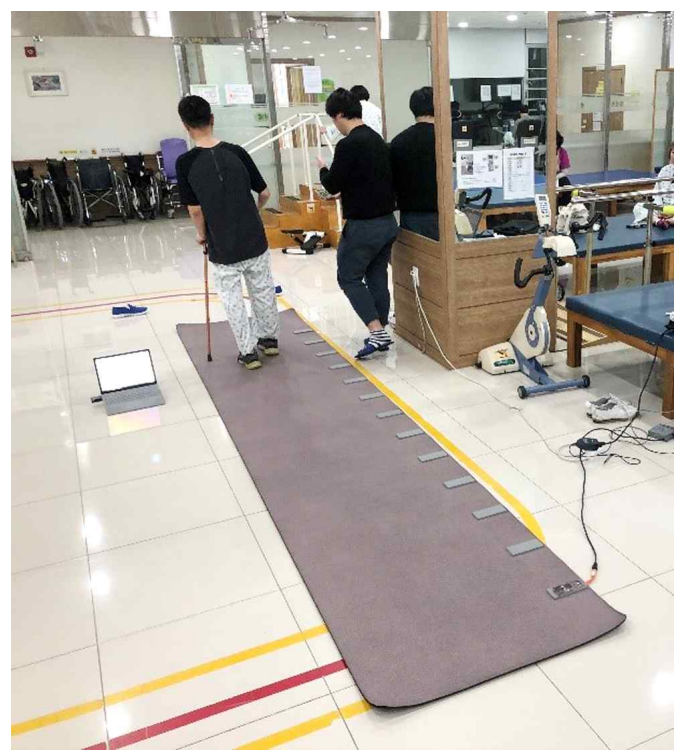

Figure 4. Assessment on the GAITRite

시간적 보행 능력과 활보장과 보장 등의 공간적 보행 특 성을 측정한 후 소프트웨어를 통해 자료 처리를 하였다 (Figure 5). 측정은 대상자를 보행로 $2 \mathrm{~m}$ 뒤에 서 있도록 한 후 ‘출발’이라는 지시에 따라 보행로 끝 $2 \mathrm{~m}$ 선에 정 지하도록 하였다. 보행 보조기와 $\mathrm{AFO}$ 보조기가 필요한 경우 착용하고 보행을 하였다. 이 검사의 측정자 내 신뢰 도는 $(\mathrm{r}=0.77 \sim 0.99)$, 측정자 간 신뢰도는 $(\mathrm{r}=0.81 \sim$ 0.99) 였다[21]. 본 연구에서는 모든 참가자는 측정 사이 에 1 분의 휴식을 취하고 연습 없이 3 회 이상 보행 측정을 실시하였고, 3 회 보행 평균값을 측정값으로 하였다.

\section{시간적, 공간적 보행 대칭성 지수}

보장과 단일 지지기 시간 대칭성 지수를 사용하여 뇌졸 중 환자 보행의 시간적, 공간적 대칭의 정도를 측정하였 다[33]. 단일 지지기 비대칭 비율은 시간적 보행 대칭성 지수를 나타내는 값으로 0 은 양쪽이 완전히 대칭임을 나 타내고 공식은 다음과 같다(공식 1). 보장 비대칭 비율은 공간적 보행 대칭성 지수를 나타내는 값으로 0 은 양쪽이 완전히 대칭임을 나타내고 공식은 다음과 같다(공식 2).

$$
1-\frac{\text { 단일지지기시간(마비측) }}{\text { 단일지지기시간(비마비측) }}
$$

공식 1. 시간적 보행 대칭성 지수

$$
1-\frac{\text { 보장(마비측) }}{\text { 보장(비마비측) }}
$$

공식 2. 공간적 보행 대칭성 지수

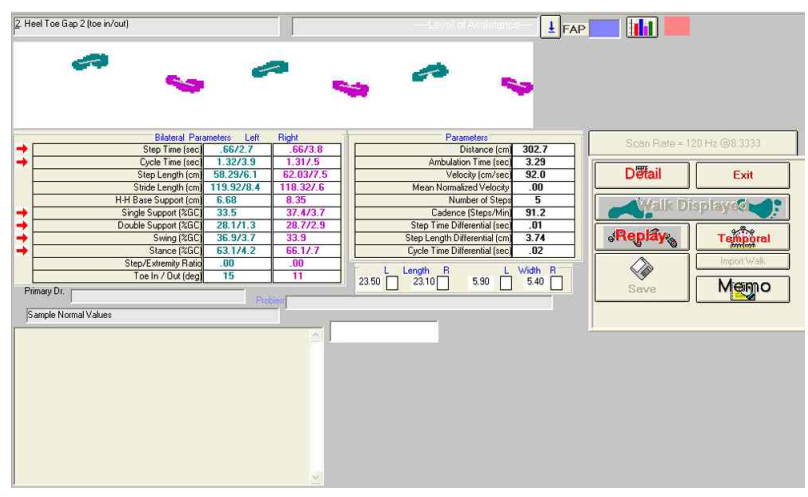

Figure 5. GAITRite(Version 3.2b, CIR System Inc., USA)

\section{자료 분석}

본 연구의 모든 작업과 통계는 SPSS (Statistics 21.0 version, IBM, USA)를 이용하여 평균과 표준편차를 산 출하였다. 전체 대상자는 Shapiro-Wilk test 정규성 검증 을 실시하여 그 결과 정규 분포하였으며, 대상자의 일반 적 특성은 기술통계를 사용하였고, 대상자의 보행 방법에 따른 시간적, 공간적 보행 변수의 차이는 이요인반복측정 분산 분석(two-way repeated ANOVA)을 사용하였다. 사 후 검증은 본페로니 검정(Bonferroni's post hoc test)을 이용하여 분석하였으며, 통계학적 유의수준은 0.05 이하 로 하였다.

\section{연구 결과}

연구에 참여한 전체 대상자는 18 명이었으며 남자는 9 명, 여자는 9명이었다. 평균 연령은 58.22세, 평균 신장은 $164.94 \mathrm{~cm}$, 평균 체중은 $63.17 \mathrm{~kg}$, 평균 유병기간은 58.5 개월이었으며 병변부위는 오른쪽 편마비 12 명, 왼쪽 편마 비 6명이었다.

\section{공기압 인솔의 마비측 체중 역치값에 따른 보행속도 분속수의 변화}

보행 속도는 피드백 없이 보행 시 $24.99 \mathrm{~cm} / \mathrm{sec}$, maximum peak pressure (MPP) 70\% 역치값에서 $27.00 \mathrm{~cm} / \mathrm{sec}$, MPP $80 \%$ 역치값에서 $29.42 \mathrm{~cm} / \mathrm{sec}$, MPP $90 \%$ 역치값 에서 $28.10 \mathrm{~cm} / \mathrm{sec}$, MPP $100 \%$ 역치값에서 $28.61 \mathrm{~cm} / \mathrm{sec}$ 로 MPP $80 \%$ 역치값에서 가장 증가하였으며 피드백 없이 보행을 시행하였을 때와 유의한 차이가 나타났다 $(\mathrm{p}<0.05)$.

분속수는 피드백 없이 보행 시 $0.15 \mathrm{step} / \mathrm{sec}, \mathrm{MPP} 70 \%$ 역치값에서 $0.19 \mathrm{step} / \mathrm{sec}, \mathrm{MPP} 80 \%$ 역치값에서 0.13 step/sec, MPP 90\% 역치값에서 $0.14 \mathrm{step} / \mathrm{sec}$, MPP $100 \%$ 역치값에서 $0.11 \mathrm{step} / \mathrm{sec}$ 로 MPP $70 \%$ 역치값에서 가장 증가하였으나 조건 간 유의한 차이를 보이지 않았다. 
Table 1. General Characteristics and Test of Homogeneity

$(n=18)$

\section{Characteristics}

\begin{tabular}{lll}
\hline Age $($ year $)$ & & $58.22(5.86)^{\mathrm{a}}$ \\
Height $(\mathrm{cm})$ & & $164.94(4.30)$ \\
Weight $(\mathrm{kg})$ & & $63.71(8.12)$ \\
Stroke duration (month) & & $58.5(28.11)$ \\
\hline \multirow{2}{*}{ Sex } & Male & $9(50 \%)^{\mathrm{b}}$ \\
\hline \multirow{2}{*}{ Affected side } & Female & $9(50 \%)$ \\
\hline
\end{tabular}

${ }^{\mathrm{a}}$ The values are presented mean (SD)

${ }^{\mathrm{b}}$ The values are presented number (\%)

\section{공기압 인솔의 마비측 체중 역치값에 따른 단일 지지기 시간의 변화}

마비측 단일 지지기 시간은 피드백 없이 보행 시 0.38 $\mathrm{sec}, \mathrm{MPP} 70 \%$ 역치값에서 $0.43 \mathrm{sec}$, MPP $80 \%$ 역치값 에서 $0.43 \mathrm{sec}$, MPP $90 \%$ 역치값에서 $0.43 \mathrm{sec}$, MPP $100 \%$ 역치값에서 $0.45 \mathrm{sec}$ 로 MPP $100 \%$ 역치값에서 가 장 증가하였으며 피드백 없이 보행을 시행하였을 때와 유 의한 차이가 나타났다 $(\mathrm{p}<0.05)$.

비마비측 단일 지지기 시간은 피드백 없이 보행 시 $0.54 \mathrm{sec}, \mathrm{MPP} 70 \%$ 역치값에서 $0.53 \mathrm{sec}, \mathrm{MPP} 80 \%$ 역 치값에서 $0.55 \mathrm{sec}, \mathrm{MPP} 90 \%$ 역치값에서 $0.54 \mathrm{sec}$, MPP $100 \%$ 역치값에서 $0.54 \mathrm{sec}$ 로 MPP $80 \%$ 역치값에 서 가장 증가 되었으며 MPP $70 \%$ 역치값과 유의한 차이 가 있는 것으로 나타났다 $(\mathrm{p}<0.05)$

\section{공기압 인솔의 마비측 체중 역치값에 따른 보장의 변화}

마비측 보장은 피드백 없이 보행 시 $29.82 \mathrm{~cm}, \mathrm{MPP}$ $70 \%$ 역치값에서 $33.27 \mathrm{~cm}, \mathrm{MPP} 80 \%$ 역치값에서 34.44 $\mathrm{cm}, \mathrm{MPP} 90 \%$ 역치값에서 $32.81 \mathrm{~cm}, \mathrm{MPP} 100 \%$ 역치
값에서 $31.41 \mathrm{~cm}$ 로 $\mathrm{MPP} 80 \%$ 역치값에서 가장 증가하 였으며 피드백 없이 보행을 시행하였을 때와 유의한 차이 가 나타났다 $(\mathrm{p}<0.05)$.

비마비측 보장은 피드백 없이 보행 시 $27.15 \mathrm{~cm}, \mathrm{MPP}$ $70 \%$ 역치값에서 $29.23 \mathrm{~cm}$, MPP $80 \%$ 역치값에서 30.70 $\mathrm{cm}, \mathrm{MPP} 90 \%$ 역치값에서 $31.41 \mathrm{~cm}, \mathrm{MPP} 100 \%$ 역치 값에서 $31.88 \mathrm{~cm}$ 로 MPP $100 \%$ 역치값에서 가장 증가하 였으며 피드백 없이 보행을 시행하였을 때와 유의한 차이 가 나타났다 $(\mathrm{p}<0.05)$

\section{공기압 인솔의 마비측 체중 역치값에 따른 활보장의 변화}

마비측 활보장은 피드백 없이 보행 시 $53.07 \mathrm{~cm}, \mathrm{MPP}$ $70 \%$ 역치값에서 $57.35 \mathrm{~cm}, \mathrm{MPP} 80 \%$ 역치값에서 61.47 $\mathrm{cm}, \mathrm{MPP} 90 \%$ 역치값에서 $59.89 \mathrm{~cm}, \mathrm{MPP} 100 \%$ 역치 값에서 $59.83 \mathrm{~cm}$ 로 $\mathrm{MPP} 80 \%$ 역치값에서 가장 증가 되 었으며 피드백 없이 보행을 시행하였을 때와 유의한 차이 가 나타났다 $(\mathrm{p}<0.05)$.

비마비측활보장은 피드백 없이 보행 시 $53.68 \mathrm{~cm}$, $\mathrm{MPP} 70 \%$ 역치값에서 $57.60 \mathrm{~cm}, \mathrm{MPP} 80 \%$ 역치값에서

Table 2. Changes of Gait Velocity and Cadence Depending on the Maximum Peak Pressure of the Insole

$(\mathrm{n}=18)$

\begin{tabular}{lllll}
\hline & Velocity $(\mathbf{c m} / \mathbf{s e c})$ & $\mathbf{F}(\boldsymbol{p})$ & Cadence(step/sec) & $\mathbf{F}(\boldsymbol{p})$ \\
\hline Without feedback (A) & $24.99(12.15)$ & & $0.15(0.10)$ & \\
MPP 70\% threshold (B) & $27.00(12.08)$ & & $0.19(0.28)$ & 0.782 \\
MPP 80\% threshold (C) & $29.42(13.90)$ & 9.417 & $0.13(0.12)$ & $(0.553)$ \\
MPP 90\% threshold (D) & $28.10(13.93)$ & & $0.14(0.12)$ & $0.11(0.07)$ \\
MPP 100\% threshold (E) & $28.61(13.16)$ & & \\
\hline
\end{tabular}

The values are mean (SD)

MPP: maximum peak pressure. 
Table 3. Changes of Single Stance Time Depending on the Maximum Peak Pressure of the Insole

\begin{tabular}{|c|c|c|c|c|}
\hline & $\begin{array}{l}\text { Affected side single stance } \\
\text { time (sec) }\end{array}$ & $\mathbf{F}(p)$ & $\begin{array}{l}\text { Unaffected side single stance } \\
\text { time (sec) }\end{array}$ & $\mathbf{F}(p)$ \\
\hline Without feedback (A) & $0.38(0.14)$ & & $0.54(0.16)$ & \\
\hline MPP 70\% threshold (B) & $0.43(0.14)$ & & $0.53(0.12)$ & \\
\hline MPP 80\% threshold (C) & $0.43(0.14)$ & $25.326(0.000)$ & $0.55(0.14)$ & $3.637(0.027)$ \\
\hline MPP 90\% threshold (D) & $0.43(0.13)$ & & $0.54(0.14)$ & \\
\hline MPP $100 \%$ threshold $(E)$ & $0.45(0.14)$ & & $0.54(0.15)$ & \\
\hline
\end{tabular}

The values are mean (SD)

MPP: maximum peak pressure

Table 4. Changes of Step Width Depending on the Maximum Peak Pressure of the Insole

$(\mathrm{n}=18)$

\begin{tabular}{|c|c|c|c|c|}
\hline & $\begin{array}{l}\text { Affected side step width } \\
\text { (cm) }\end{array}$ & $\mathbf{F}(p)$ & $\begin{array}{l}\text { Unaffected side step width } \\
(\mathrm{cm})\end{array}$ & $\mathbf{F}(p)$ \\
\hline Withoutfeedback (A) & $29.82(11.12)$ & & $27.15(9.19)$ & \\
\hline MPP 70\% threshold (B) & $33.27(10.06)$ & & $29.23(10.26)$ & \\
\hline MPP 80\% threshold (C) & $34.44(10.72)$ & $25.326(0.000)$ & $30.70(9.95)$ & $29.462(0.000)$ \\
\hline MPP 90\% threshold (D) & $32.81(9.90)$ & & $31.41(10.00)$ & \\
\hline MPP $100 \%$ threshold $(\mathrm{E})$ & $31.41(9.38)$ & & $31.88(9.00)$ & \\
\hline
\end{tabular}

The values are mean (SD)

MPP: maximum peak pressure

Table 5. Changes of Temporal Symmetry Index and Spatial Symmetry Index Depending on the Maximum Peak Pressure of the Insole

$(\mathrm{n}=18)$

\begin{tabular}{|c|c|c|c|c|}
\hline & Temporal symmetry index & $\mathbf{F}(p)$ & Spatial symmetry index & $\mathbf{F}(p)$ \\
\hline Withoutfeedback (A) & $0.29(0.12)$ & & $0.15(0.10)$ & \\
\hline MPP 70\% threshold (B) & $0.19(0.13)$ & & $0.19(0.28)$ & \\
\hline MPP 80\% threshold (C) & $0.22(0.11)$ & $12.791(0.000)$ & $0.13(0.12)$ & $0.782(0.553)$ \\
\hline MPP 90\% threshold (D) & $0.20(0.10)$ & & $0.14(0.12)$ & \\
\hline MPP $100 \%$ threshold (E) & $0.16(0.06)$ & & $0.11(0.07)$ & \\
\hline
\end{tabular}

The values are mean (SD)

MPP: maximum peak pressure

$61.01 \mathrm{~cm}, \mathrm{MPP} 90 \%$ 역치값에서 $60.06 \mathrm{~cm}$, MPP 100\% 역치값에서 $60.22 \mathrm{~cm}$ 로 $\mathrm{MPP} 80 \%$ 역치값에서 가장 증 가 되었으며 피드백 없이 보행을 시행하였을 때와 유의한 차이가 나타났다 $(\mathrm{p}<0.05)$.

\section{고찰}

본 연구는 뇌졸중 환자에게 청각적 피드백으로 뒤꿈치 닿기를 강조한 공기압 인솔을 착용하였을 때 보행에 대한 영향과 역치값에 따른 뇌졸중 환자의 보행 능력의 변화를
알아보고자 하였다.

뇌졸중 환자는 보행 시 마비측 하지에 발등 굽힘이 제 한적이며[13], 초기 입각기 시 발뒤꿈치가 지면에 접촉하 기 어려워 마비측 하지의 지지기 시간과 보폭이 감소한다 [14]. 이러한 뇌졸중 환자의 보행은 시간적, 공간적 보행 변수의 비대칭 비율이 증가하는 것이 특징이다[34]. 뇌졸 중 환자의 비대칭적인 보행은 낙상 확률을 증가시킬 수 있고[11], 보행 시 에너지 효율을 감소시킨다[9][10].

통증, 제한된 관절 가동 범위 및 하지의 근육 기능 장 애가 종종 보행에 영향을 미치지 않기 때문에 뇌졸중 환 
자에게 마비측 하지의 체중 부하량을 정량화하는 것은 매 우 중요하다[29]. 뇌졸중 환자의 압력 센서 인솔에 의해 수집된 체중 부하량은 보행 전략을 평가하고 보행을 향상 시키는 유용한 도구가 될 수 있다[15].

$\operatorname{Kim}$ 등[14]은 뇌졸중 환자에게 인솔 뒤꿈치 부분에 압 력 센서를 부착하여 마비측 인솔에 역치값 이상의 압력이 감지되면, 신호음이 발생 되도록 하여 보행 훈련을 시행 한 결과 정적, 동적 균형 능력과 보행 능력의 향상이 나타 났다. 선행연구에서 압력 센서의 역치값은 1 단계(체중의 $40 \%)$ 에서 6 단계(체중의 $65 \%$ )까지 단계별로 체중의 $5 \%$ 씩 증가하였다. 뇌졸중 환자의 마비측 인솔의 압력 값을 측정할 수가 없어 초기 훈련 시 적절한 역치값을 설정할 수가 없고, 모든 환자가 낮은 압력 역치값에서부터 시작 하여 점진적으로 단계를 샹향 조절하여 훈련을 실시해야 하는 단점이 있다. 본 연구에 사용된 공기압 인솔은 실시 간으로 최대 피크 압력 측정이 가능하여 뇌졸중 환자의 보행 능력에 맞는 역치값 설정과 체중의 $0 \sim 300 \%$ 까지 폭넓은 범위의 역치값을 설정할 수 있으므로 보다 효율적 이고 정확하게 청각적 피드백을 제공할 수 있다.

lsakov[29]는 정상인에게 힘판과 공기압 인솔을 비교하 여 장비의 유효성을 확인하는 연구를 진행하였다. 연구에 사용된 인솔은 양측에 각각 2 개의 공기압 센서가 부착되 어 있고 설정된 체중 값에 도달했을 때 청각 신호가 생성 되도록 설계되었고, 정상인을 대상으로 힘판과 공기압 인 솔이 유의한 상관관계가 있었다고 보고하였다 $(\mathrm{p}=0.0004)$.

본 연구는 GAITRite를 이용하여 청각적 피드백으로 뒤꿈치 닿기를 강조한 공기압 인솔 착용하였을 때 역치값 에 따른 뇌졸중 환자의 시간적, 공간적 보행 변수의 변화, 그리고 단일 지지기 시간 비대칭 비율과 보장 비대칭 비 율을 사용하여 양측 하지의 시간적, 공간적 대칭성 지수 를 측정하였다.

대상자들의 보행 변수는 피드백 없이 보행하였을 때와 비교하여 보행 속도, 비마비측 단일 지지기 시간, 마비측과 비마비측활보장, 마비측 보장은 최대 피크 압력의 $80 \%$ 역 치값에서 유의하게 증가하였고, 마비측 단일 지지기 시간, 시간적 보행 대칭성 지수, 비마비측 보장은 최대 피크 압 력의 $100 \%$ 역치값에서 유의하게 증가한 것으로 나타났다.

디딤기 단계에서 마비측 하지에 체중 부하를 증가시키 는 것은 뇌졸중 환자의 보행 능력을 향상하기 위해선 필 수적이다[35]. 마비측 압력 센서에 의해 발생하는 청각적 피드백은 감각이 상실된 환자에게 자세 조절에 대한 추가 적인 정보를 제공할 수 있으며, 마비측에 훈련의 목적을 반복적으로 자극할 수 있다[36].

청각적 피드백은 뇌졸중 환자에게 감각 정보를 제공하 여 동작의 오류를 쉽게 찾을 수 있게 하고 운동 기능을 수정할 수 있도록 도와주며[27], 뇌졸중을 포함한 다양한
신경 손상 및 또는 질병을 가진 환자의 보행 향상에 효과 적이다[18]. 청각적 피드백은 주로 마비측 하지의 단일 지 지기 단계에서 적용되며, 비마비측은 지면에서 발이 들어 올려진다. 이 동작은 대칭적인 자세를 촉진하고, 마비측으 로 체중 지지를 하게 되어 마비측의 근육 활동의 활성화가 나타난다[37]. Shin 등[38]의 연구는 7명의 뇌성마비 환자 와 11 명의 뇌졸중 환자를 대상으로 청각적 피드백 보행 훈 련을 시행한 결과, 뇌졸중 환자의 유각기와 입각기의 대칭 성 향상을 보고하여 본 연구의 결과를 뒷받침하고 있다.

이전 연구에서 뇌졸중 환자에게 신발에 센서에 의한 청 각적 피드백은 보행 속도의 증가는 보장의 증가와 함께 나타난다고 보고하였다[39]. 본 연구에서의 최대 피크 압 력의 $80 \%$ 역치값에서 보행 속도, 활보장, 마비측 보장이 증가한 결과는 선행연구와 일치하였으나, 비마비측 단일 지지기 시간이 가장 증가한 결과값으로 보아 보행 변수의 긍정적인 변화인지 확인하긴 어렵다.

뇌졸중 환자의 보행은 마비측 하지의 단일 지지기 시간 이 비마비측 보다 짧기 때문에 비마비측 보장이 마비측 하지의 보장 보다 짧다[5][20]. 공기압 인솔[29], 압력게이 지 인솔[40]을 착용하여 뇌졸중 환자를 대상으로 청각적 피드백 보행 훈련을 시행한 연구는 마비측 하지의 체중 부하량과 디딤이 시간이 유의하게 증가를 보고하였다. Sungkarat 등 [33]에 의하면 뇌졸중 환자에게 압력 센서 인솔을 착용한 청각적 피드백 보행 훈련으로 인한 마비측 체중 부하 증가는 보장과 시간적, 공간적 보행 대칭성의 향상과 상관 관계가 있다고 보고 하여 본 연구의 결론을 뒷받침하고 있다.

본 연구에서 공기압 인솔의 마비측 최대 피크 압력의 $100 \%$ 역치값일 때 보행 시 신호음을 발생시키기 위해서 뇌졸중 환자의 최대 노력으로 체중 부하를 실시한 결과, 마비측 단일 지지기 시간 증가로 인한 시간적 보행 대칭 성 지수와 비마비측 보장의 향상이 나타나게 된 것으로 생각한다.

본 연구의 제한점으로는 뇌졸중 환자 보행 시 보행 속 도와 시간에 대한 통제가 없었기 때문에 시간적, 공간적 보행 대칭성 지수에 대한 통계적으로 오류가 발생할 가능 성을 배제할 수 없다는 점이다. 또한, 실험 대상자 수가 적어 연구결과에 대해 뇌졸중 환자 전체로 일반화하는데 어려움이 있다.

본 연구의 결과에서는 공기압 인솔을 착용한 청각적 피 드백 보행이 보행 속도, 단일 지지기 시간, 보장, 활보장, 시간적 보행 대칭성을 향상 시켜 긍정적인 효과를 나타내 었다. 향후 공기압 인솔을 착용하여 뇌졸중 환자에게 청 각적 피드백 보행 훈련 시 목적에 맞게 체중 역치값을 설 정하여 훈련을 시행한다면 뇌졸중 환자의 보행 능력 향상 에 도움이 될 것이라고 생각한다. 


\section{이해 충돌}

본 연구의 저자들은 연구, 저자권, 및 출판과 관련하여 잠재적인 이해충돌이 없음을 선언합니다.

\section{감사의 글}

이 성과는 2020년도 정부(미래창조과학부)의 재원으로 한국연구재단의 지원을 받아 수행된 연구임 (No. 2018R1 C1B5036917).

\section{참고문헌}

1. Bates, M., Choi, J. Y., Glasberg, J. J., \& Graham, G. D. (2005). Management of adult stroke rehabilitation care. Stroke.2005;36:e100.

2. Strong, K., Mathers, C., \& Bonita, R. Preventing stroke: saving lives around the world. The Lancet Neurol. 2007;6(2):182-187.

3. Duncan, P. W., Zorowitz, R., Bates, B., Choi, J. Y., Glasberg, J. J., Graham, G. D., et al. Management of adult stroke rehabilitation care: a clinical practice guideline. Stroke. 2005;36(9):e100-e143.

4. Pappas E, Salem Y. Overground physical therapy gait training for chronic stroke patients with mobility deficits. Cochrane database of systematic reviews. 2009.

5. Olney, S. J., \& Richards, C. Hemiparetic gait following stroke. Part I: Characteristics. Gait Posture. 1996;4(2):136-148.

6. Brandstater, M. E., de Bruin, H., Gowland, C., \& Clark, B. M. Hemiplegic gait: analysis of temporal variables. Arch Phys Med Rehabil. 1983;64(12): 583-587.

7. Wall, J. C., \& Ashburn, A. Assessment of gait disability in hemiplegics. Hemiplegic gait. Scand $\mathrm{J}$ Rehabil Med. 1979;11(3):95-103.

8. Jørgensen, H. S., Nakayama, H., Raaschou, H. O., \& Olsen, T. S. Recovery of walking function in stroke patients: The Copenhagen Stroke Study. Arch Phys Med Rehabil. 1995;76(1):27-32.

9. Lewek, M. D., Feasel, J., Wentz, E., Brooks Jr, F. P., \& Whitton, M. C. Use of visual and proprioceptive feedback to improve gait speed and spatiotemporal symmetry following chronic stroke: a case series. Phys Ther. 2012;92(5):748-756.

10. Louis N. Awad, J. A. P., Ryan T. Pohlig, Stuart A. Binder-Macleod, and Darcy S. Reisman. Walking Speed and Step Length Asymmetry Modify the Energy Cost of Walking After Stroke. Neurorehabil Neural Repair. 2014;29(5):416-423.

11. Weerdesteijn, V., Niet, M. d., Van Duijnhoven, H., \&Geurts, A. C. Falls in individuals with stroke. J Rehabil Res Dev. 2008;45(8):1195-1214

12. Patterson, K. K., Gage, W. H., Brooks, D., Black, S. E., \& Mcllroy, W. E. Evaluation of gait symmetry after stroke: a comparison of current methods and recommendations for standardization. GaitPosture. 2010;31(2):241-246.

13. Bensoussan, L., Mesure, S., Viton, J.-M., \&Delarque, A. Kinematic and kinetic asymmetries in hemiplegic patient's gait initiation patterns. J Rehabil Med. 2006;38(5):287-294.

14. Jung-Doo Kim, Y.-J. C., Hye-JinYoun. Effects of Emphasized Initial Contact Auditory Feedback Gait Training on Balance and Gait in Stroke Patients. J Korean Soc Phys Med. 2015;10(4):49-57.

15. Munoz-Organero, M., Parker, J., Powell, L., \& Mawson, S. Assessing walking strategies using insole pressure sensors for stroke survivors. Sensors. 2016;16(10):1631.

16. Stein, R. B., Everaert, D. G., Thompson, A. K., Chong, S. L., Whittaker, M., Robertson, J., et al. Long-term therapeutic and orthotic effects of a foot drop stimulator on walking performance in progressive and nonprogressive neurological disorders. Neurorehabil and neural repair. 2010;24(2):152-167.

17. Bohannon, R. W. Rolling to the nonplegic side: Influence of teaching and limb strength in hemiplegic stroke patients. ClinRehabil. 1988;2(3):215-218.

18. Thaut, M. H., McIntosh, G. C., \& Rice, R. R. Rhythmic facilitation of gait training in hemiparetic stroke rehabilitation. J Neurol Sci. 1997;151(2): 207-212.

19. Michael, K. M., Allen, J. K., \&Macko, R. F. Reduced ambulatory activity after stroke: the role of balance, gait, and cardiovascular fitness. Arch Phys Med Rehabil. 2005;86(8):1552-1556.

20. Patterson, K. K., Parafianowicz, I., Danells, C. J., Closson, V., Verrier, M. C., Staines, W. R., et al. (2008). Gait asymmetry in community-ambulating stroke survivors. Arch Phys Med Rehabil. 2008;89(2): 


\section{4-310.}

21. Wong, J. S., Jasani, H., Poon, V., Inness, E. L., McIlroy, W. E., \& Mansfield, A. Inter-and intra-rater reliability of the GAITRite system among individuals with sub-acute stroke. GaitPosture. 2014;40(1):259-261.

22. Mirelman, A., Bonato, P., \& Deutsch, J. E. Effects of training with a robot-virtual reality system compared with a robot alone on the gait of individuals after stroke. Stroke. 2009;40(1):169-174.

23. Dundar, U., Toktas, H., Solak, O., Ulasli, A., \& Eroglu, S. A comparative study of conventional physiotherapy versus robotic training combined with physiotherapy in patients with stroke. Top Stroke Rehabil. 2014;21(6):453-461.

24. Cha, Y.-J., Kim, J.-D., Choi, Y.-R., Kim, N.-H., \& Son, S.-M. Effects of gait training with auditory feedback on walking and balancing ability in adults after hemiplegic stroke: a preliminary, randomized, controlled study. Int JRehabilRes. 2018;41(3):239-243.

25. Mansfield, A., Wong, J. S., Bryce, J., Brunton, K., Inness, E. L., Knorr, S., et al. Use of accelerometer-based feedback of walking activity for appraising progress with walking-related goals in inpatient stroke rehabilitation: a randomized controlled trial. Neurorehabil and Neural Repair. 2015;29(9): 847-857.

26. Rosalyn Stanton a, L. A. a., Catherine M Dean b, Elisabeth Preston c. Biofeedback improves performance in lower limb activities more than usual therapy in people following stroke: a systematic review. JPhys Ther. 2016;63(1):11-16.

27. Batavia, M., Gianutsos, J. G., \&Kambouris, M. An augmented auditory feedback device. Arch Phys Med Rehabil. 1997;78(12):1389-1392.

28. Mawson, S., Nasr, N., Parker, J., Davies, R., Zheng, H., \& Mountain, G. A personalized self-management rehabilitation system with an intelligent shoe for stroke survivors: a realist evaluation. JMIR Rehabil Assist Technol. 2016;3(1):e1.

29. Isakov, E. Gait rehabilitation: a new biofeedback device for monitoring and enhancing weight-bearing over the affected lower limb. Europa Medicophys. 007;43(1):21.

30. Khoo, I.-H., Marayong, P., Krishnan, V., Balagtas, M. N., \& Rojas, O. Design of a biofeedback device for gait rehabilitation in post-stroke patients. Paper presented at the 2015 IEEE 58th international mid- west symposium on circuits and systems (MWSCAS); 2015 Aug 2-5, Fort Collins, CO, USA

31. Haggard, P., Cockburn, J., Cock, J., Fordham, C., $\&$ Wade, D. Interference between gait and cognitive tasks in a rehabilitating neurological population. J Neurol Neurosurg Psychiatry. 2000;69(4):479-486.

32. Aruin, A. S., Hanke, T. A., \& Sharma, A. Base of support feedback in gait rehabilitation. Int $\mathrm{J}$ Rehabil Res. 2003;26(4):309-312.

33. Sungkarat, S., Fisher, B. E., \&Kovindha, A. Efficacy of an insole shoe wedge and augmented pressure sensor for gait training in individuals with stroke: a randomized controlled trial. Clin Rehabil. 2011;25(4):360-369.

34. Von Schroeder, H. P., Coutts, R. D., Lyden, P. D., Billings, E., \& Nickel, V. L. Gait parameters following stroke: a practical assessment. J of RehabilRes Dev. 1995;32:25-25.

35. Ochi, M., Wada, F., Saeki, S., \& Hachisuka, K. Gait training in subacute non-ambulatory stroke patients using a full weight-bearing gait-assistance robot: A prospective, randomized, open, blinded-endpoint trial. J Neurol Sci. 2015;353(1-2):130-136.

36. Oscari, F., Secoli, R., Avanzini, F., Rosati, G., \&Reinkensmeyer, D. J. Substituting auditory for visual feedback to adapt to altered dynamic and kinematic environments during reaching. Exp Brain Res. 2012;221(1):33-41.

37. Boonsinsukh, R., Panichareon, L., \&Phansuwan-Pujito, P. Light touch cue through a cane improves pelvic stability during walking in stroke. Arch Phys Med Rehabil. 2009;90(6):919-926.

38. Shin, Y.-K., Chong, H. J., Kim, S. J., \& Cho, S.-R. Effect of rhythmic auditory stimulation on hemiplegic gait patterns. Yonsei Med J. 2015;56(6): 1703-1713.

39. Johnson, E. G., Lohman, E. B., Rendon, A., Dobariya, E. G., Ramani, S. S., \& Mayer, L. E. The immediate effects of a novel auditory and proprioceptive training device on gait after stroke. ClinPract, 2011;1(3):e46.

40. Ki, K.-I., Kim, M.-S., Moon, Y., \& Choi, J.-D. Effects of auditory feedback during gait training on hemiplegic patients' weight bearing and dynamic balance ability. J Phys TherSci. 2015;27(4): 1267-1269. 